\title{
Adapting to climate change in The Netherlands: an inventory of climate adaptation options and ranking of alternatives
}

\author{
K. de Bruin · R. B. Dellink • A. Ruijs • L. Bolwidt • A. van Buuren • J. Graveland • \\ R. S. de Groot • P. J. Kuikman • S. Reinhard • R. P. Roetter • V. C. Tassone • \\ A. Verhagen - E. C. van Ierland
}

Received: 12 September 2007 / Accepted: 11 October 2008 / Published online: 10 April 2009

(C) The Author(s) 2009. This article is published with open access at Springerlink.com

\begin{abstract}
In many countries around the world impacts of climate change are assessed and adaptation options identified. We describe an approach for a qualitative and quantitative assessment of adaptation options to respond to climate change in the
\end{abstract}

\footnotetext{
K. de Bruin · R. B. Dellink · A. Ruijs · E. C. van Ierland ( $\square)$

Environmental Economics and Natural Resources Group, Wageningen University, Hollandseweg 1, 6706 KN Wageningen, The Netherlands

e-mail: ekko.vanierland@wur.nl

R. B. Dellink

Institute for Environmental Studies, VU University Amsterdam, Amsterdam, The Netherlands

L. Bolwidt

RIZA, Institute for Inland Water Management and Waste Water Treatment,

Lelystad, The Netherlands
}

A. van Buuren

Department of Public Administration, Erasmus Universiteit, Rotterdam, The Netherlands

J. Graveland

RIKZ, National Institute for Coastal and Marine Management, Middelburg, The Netherlands

\section{R. S. de Groot · V. C. Tassone}

Environmental Systems Analysis, Wageningen UR, Wageningen, The Netherlands

P. J. Kuikman · R. P. Roetter

Alterra, Wageningen UR, Wageningen, The Netherlands

S. Reinhard

LEI, Wageningen UR, Wageningen, The Netherlands

S. Reinhard

BSIK Leven met Water, Gouda, The Netherlands

A. Verhagen

Plant Research International, Wageningen UR, Wageningen, The Netherlands 
Netherlands. The study introduces an inventory and ranking of adaptation options based on stakeholder analysis and expert judgement, and presents some estimates of incremental costs and benefits. The qualitative assessment focuses on ranking and prioritisation of adaptation options. Options are selected and identified and discussed by stakeholders on the basis of a sectoral approach, and assessed with respect to their importance, urgency and other characteristics by experts. The preliminary quantitative assessment identifies incremental costs and benefits of adaptation options. Priority ranking based on a weighted sum of criteria reveals that in the Netherlands integrated nature and water management and risk based policies rank high, followed by policies aiming at 'climate proof' housing and infrastructure.

\section{Introduction}

Adaptation to climate change has received increased attention in the scientific and policy debate, and is seen as complementary to mitigation (UNFCCC 1997; McCarthy et al. 2001). Adaptation can be defined as: "adjustment in ecological, social or economic systems in response to actual or expected climatic stimuli and their effects or impacts" (Smit et al. 1999). The related concept of 'adaptive capacity' refers to the 'potential or ability of a system, region, or community to adapt to the effects or impacts of climate change' (Smit et al. 2001; Smit and Pilifosova 2003), mostly interpreted to reflect only adjustments to moderate potential damages, not to extreme scenarios. The report 'Impacts, adaptation and vulnerability' of the Intergovernmental Panel on Climate Change (IPCC) defines adaptive capacity as: "the ability of a system to adjust to climate change (including climate variability and extremes), to moderate potential damages, to take advantage of opportunities, or to cope with the consequences" (IPCC 2007). The Stern Review states that: "adaptation will be crucial in reducing vulnerability to climate change and is the only way to cope with the impacts that are inevitable over the next few decades" (Stern 2006). Anticipatory adaptation is seen as an essential part of the optimal response to climate change, as it is likely much less expensive than relying on reactive adaptation only (Fankhauser et al. 1999). Climate change represents a complex, strategic risk, and thus robust adaptation options are required that will provide benefits under various future climate scenarios (Willows and Connell 2003).

Adaptation assessments are developed and conducted with the aim to identify and evaluate adaptation options. They serve as input for national adaptation strategies, or focus on specific sectors, such as the water (Rosenzweig et al. 2007) and health (Ebi and Burton 2008) sector. In many countries around the world the impacts of climate change are assessed and adaptation options identified. For example, Canada (Lemmen et al. 2008), Finland (MMM 2005) and the United Kingdom (DEFRA 2006) have conducted national adaptation assessments or developed national strategies to adapt to climate change. The Adaptation Policy Frameworks for Climate Change (UNDP 2005) and the National Programmes of Action are programmes which provide a guideline for developing countries to identify priority activities that respond to their urgent and immediate needs with regard to adaptation to climate change (UNFCCC 2007). Füssel (2007), in a review of general assessment approaches related to adaptation planning, points out that adaptation assessments are relevant in different contexts, both in climate impact and vulnerability assessments and for 
adaptation planning and policy-making (Burton et al. 2002; Füssel and Klein 2006). Tol et al. (2008) states that "adaptation assessment must consider the full context in which adaptation takes place, including the factors that determine the capacity of the country or system to adapt". By involving local stakeholders and experts in the development of a national adaptation strategy the gap between the top-down and bottom-up approaches to adaptation can be bridged, thereby providing the national government the ability to reach optimal policy decisions about adaptation when considering the allocation of scare resources.

For the Netherlands the possible consequences of climate change have been documented in various reports, including the Environmental Balance (RIVM 2004), the Climate Policy report commissioned by the Parliament (Rooijers et al. 2004) and the Climate reports of the Royal Netherlands Meteorological Institute (KNMI 2003, 2006). Most studies agree on the fact that climate change will take place, in spite of all mitigation efforts. Thus, mitigation alone is not sufficient to offset climate change in the Netherlands. The Ministry of Housing, Spatial Planning and the Environment initiated a programme, the 'Routeplanner project', to develop a national adaptation strategy for the Netherlands. To prepare this strategy the national research programme on climate change and spatial planning commissioned a study on adaptation options (Van Ierland et al. 2007).

The challenge for the Netherlands-as well as for other countries-is to harmonize a national adaptation policy with its spatial planning policy. The focus will be on developing more robust systems including technical solutions and improved control and risk management systems, and combine this with improved spatial planning. To make the Netherlands 'climate proof', a wide set of policy instruments can be used, ranging from financial instruments (e.g. taxes, subsidies or insurance arrangements) or command and control instruments (e.g. spatial planning or technology requirements) to institutional approaches (e.g. institutional reform, or education and communication). Systematic assessment of options that are technically, economically, and politically feasible could enable policymakers to make well-informed choices about different adaptation options.

The main aim of this paper is to outline the approach that was used in the qualitative and quantitative assessment and the ranking system of identified potential adaptation options to respond to climate change in the Netherlands in connection to spatial planning. We also report on the preliminary results of the study and discuss the strengths and weaknesses of the approach.

The assessment started with the selection of a climate change scenario relevant for the Netherlands for the period up to 2050, based on the scenarios of the Royal Meteorological Institute (KNMI 2003, 2006). The study has the character of a "what if" setting where it is assumed that the selected scenario of the KNMI represents the characteristics of climate change for average temperature change, rainfall patterns and sea level rise for the Netherlands. Based on this starting point the assessment includes the following aspects: (1) identification of adaptation options in the Netherlands, based on literature study and consultation of stakeholders; (2) a qualitative assessment of the characteristics of the options; (3) definition of criteria used to make a ranking of the options, based on expert judgements; (4) determining the scores of the options on the various criteria; (5) determining the weights to be used in the Multi-Criteria Analysis for the ranking of the options and (6) the actual ranking and an interpretation of the results. 
In addition we looked into the institutional complexities of implementing the various adaptation options, in order to be informed about the complexities that we would face when introducing adaption options in the various sectors of society. The institutional complexity was not integrated in the Multi-Criteria Analysis because we consider the issue of institutional complexity substantially different from the questions of what adaptation options would be important to consider. By combining information on the highly ranking options and their institutional complexity it becomes possible to develop an adaptation strategy that deals with the priority options and that can focus on solving the institutional barriers that may show up in the implementation.

We also identified the available information on the order of magnitude of the costs and benefits related to the introduction of adaptation options, in order to sketch the relative size of costs and benefits. However, we observed that for many options only limited information on costs and benefits was available and therefore a complete cost-benefit analysis was not possible. We made a start with compiling a database on the available costs and benefits. In more elaborated studies more complete costbenefit analysis can be made on the most relevant adaptation options, and this process is currently ongoing in the Netherlands. The paper is explicitly restricted to adaptation options in the Netherlands, but with adjustment to local conditions, this approach is relevant to other countries as well.

This paper is structured as follows. Section 2 presents the methods used to identify and assess the adaptation options including the ranking of the options based on their qualitative characteristics. Section 3 deals with the results of the assessment. Section 4 presents the discussion and conclusion.

\section{Method}

There are many approaches to arrive at a priority setting for alternative policy options. Metroeconomica (2004) identifies a full range of decision-support tools for option appraisal and regards cost-benefit analysis as a key decision support tool (Metroeconomica 2004). Willows and Connell (2003) discuss how to deal with the issue of uncertainty associated with decisions in a climate change context. Through Multi-Criteria Analysis (MCA) a ranking of alternative options can be derived. Janssen and van Herwijnen (2006) provide a toolbox for multicriteria decisionmaking. The evaluation steps of the toolbox contain a clear problem definition, which includes the identification of all alternatives, selection of a set of criteria and assessment of scores. Then the scores are standardized and the weight of each criteria is determined. For the MCA method 'weighted summation' the weights represent the trade-offs between the criteria. Through sensitivity analysis uncertainties in scores and weights can be further analysed (Janssen and van Herwijnen 2006). MCA has been used to assess climate change policy; focused on adaptation and mitigation options (e.g. Ebi and Burton 2008; Gough and Shackley 2006; Brouwer and van Ek 2004; Bell et al. 2001).

Based on a thorough analysis of the most suitable criteria that decision makers can adopt in their decision making, a multi-level MCA is carried out to categorize and rank promising and feasible adaptation options. The MCA was based on expert judgement, because the definition of the weights to be used in the analysis requires 
Table 1 KNMI climate change scenarios for The Netherlands for the year 2100

\begin{tabular}{lccc}
\hline & $\begin{array}{l}\text { Low } \\
\text { estimate }\end{array}$ & $\begin{array}{l}\text { Central } \\
\text { estimate }\end{array}$ & $\begin{array}{c}\text { High } \\
\text { estimate }\end{array}$ \\
\hline Temperature $\left({ }^{\circ} \mathrm{C}\right)$ & +1 & +2 & +4 to 6 \\
Average summer precipitation (\%) & +1 & +2 & +4 \\
Average summer evaporation (\%) & +4 & +8 & +16 \\
Average winter precipitation (\%) & +6 & +12 & +25 \\
$\begin{array}{l}\text { Annual maximum of the 10-days sum of winter } \\
\text { precipitation in the Netherlands }\end{array}$ & +10 & +20 & +25 \\
$\begin{array}{l}\text { Repetition of the 10-days sum which now occurs } \\
\quad \text { once every 100 years }(\geq 140 \mathrm{~mm} \text { ) (years) }\end{array}$ & 47 & 25 & 9 \\
Sea level rise $(\mathrm{cm})$ & & & +110 \\
\hline
\end{tabular}

Source: KNMI (2003); note that in 2006 KNMI slightly modified the scenarios

an overview of the various issues at stake. Stakeholders representing specific sectors in society would focus on the sector of their interest and would therefore be less able to provide an evaluation across sectors. Experts were invited from the scientific and the policy community and selected on the basis of their disciplinary and sectoral background (including economics, water management, agriculture, nature conservation, transportation, energy issues and public administration) and their capability to compare options across various sectors, which requires a broad multisectoral perspective. The list of experts and stakeholders represented in the research programme is given in Table 5 in "Appendix". The experts involved included professors and senior scientists from leading universities and research institutes in the Netherlands, including Wageningen University, Institute of Environmental Studies Vrije Universiteit Amsterdam and Erasmus University Rotterdam.

The system that we developed for the MCA is interactive and can be used by individual policymakers or individuals or categories of stakeholders to express their views on the scores and on the weights to be used and this allows for alternative rankings that then can be discussed. In this manner the system can clarify the issues at stake and contribute to a thorough understanding of the adaptation options and the various perspectives of stakeholders in society.

Our assessment focuses on the ranking of the adaptation options under one of the scenarios of the Royal Netherlands Meteorological Institute (KNMI 2003, 2006). The characteristics of the scenario are given in Table 1, we focused on the central estimate.

As the assessment was done in close consultation with stakeholders we have focused on a deterministic setting in which it was assumed that the changes would indeed occur according to the central scenario. In this manner we obtained a ranking of adaptation options that would be relevant under the sketched scenario. ${ }^{1}$

\footnotetext{
${ }^{1}$ In further studies it would be necessary to allow for uncertainty and to search for robust strategies that consider the uncertainty about whether climate change and its impacts will be high, medium or low. For the medium term perspective of our study (up to 2050) it was however felt that the selected scenario of the KNMI provided sufficient ground for making the inventory and ranking the options.
} 


\subsection{Identification and categorisation of adaptation options}

The adaptation options have been selected and identified on the basis of literature review and stakeholder consultation in a sectoral approach, in order to obtain the best inventory for the various sectors of the economy (see details reported in Van Ierland et al. 2007). Sectors included in the study are: agriculture, forestry, fisheries, water, energy and infrastructure. Some information is included on health, recreation and transport. Sector-specific literature on climate change and related adaptation options has been reviewed. As far as necessary and possible, this information was verified and augmented with expert knowledge from various disciplines, through individual consultations with experts, both within and outside the research team and through workshops where sectoral options were discussed in detail with stakeholders. We constructed a database to summarize the identified adaptation options and the associated effects, and to make an inventory of the institutional aspects related to their implementation. The interconnections between the adaptation options were also identified, including overlap, synergy and competition. For instance changes in water management may have important implications for nature, agriculture, recreation and safety. While there are undeniable gaps in this inventory, it does reflect the state of the art knowledge and can hence be used as a guide in policy preparation and for future research.

\subsection{Criteria for scoring adaptation options}

The adaptation options have been given scores with respect to the following criteria: (i) the importance of the option in terms of the expected gross benefits that can be obtained, (ii) the urgency of the option, reflecting the need to act soon and not later (iii) the no-regret characteristics of the option (it is good to implement, irrespective of climate change) (iv) the co-benefits to other sectors and domains and (v) the effect on climate change mitigation (for instance through changes in landuse that reduce emissions of greenhouse gases as a side effect). In defining the criteria we aimed at selecting them as such that they are complete (all relevant criteria have been included), operational (each option can be judged against each criterion), mutually independent (options are independent of each other from one criterion to the next), contain no double counting and are consistent with effects occurring over time (Dodgson et al. 2000; Keeney and Raiffa 1976). ${ }^{2}$ However, not all criteria are completely mutually exclusive, the no-regret and co-benefit criteria are closely related to each other. ${ }^{3}$ The scoring is based on subjective expert judgement and has been discussed in a workshop with external experts to validate the scores. We

\footnotetext{
${ }^{2}$ Belton and Stewart (2002) give a more detailed outline of the considerations that need to be taken into account when identifying criteria, namely value relevance, understandability, measurability, non-redundancy, independence, balancing completeness and conciseness, operationality and simplicity.

${ }^{3}$ If cost and benefits of options would be fully available, a criterion could be 'net benefits' of the option. However, data are lacking and we therefore did not include costs or benefits explicitly in the set of criteria.
} 
have invited experts with a broad overview of the problem of adaptation to make the ranking because the adaptation options cover many different aspects and sectors of society, and the ranking requires the capability to compare the various options across these sectors. Specialized stakeholders representing a specific sector would be less able to make this comparison across sectors, but of course they were valuable in identifying adaptation options relevant to their sector.

The importance (i.e. effectiveness in avoiding damages) of an option reflects the level of necessity to implement the option in order to avoid negative impacts. These options can reduce major damages related to climate change. In principle they generate substantial gross benefits (avoided damages), though potentially at high costs.

The urgency of the option relates to the need of implementing the adaptation option immediately or whether it is possible to defer action to a later point in time. Investments with a long lead time, or investments that have a long life time and conservation of the current situation require early action, and therefore potentially a long delay before implementing the option will make it redundant, much more costly or even impossible. Note that a high score on urgency does not necessarily imply that the option deserves a very high final ranking. It indicates that postponing action may result in higher costs or irreversible damage.

In assessing the economic characteristics of various adaptation options a distinction is made between no-regret options and options with co-benefits. No-regret options are the adaptation options for which non-climate related benefits, such as improved air quality, will exceed the costs of implementation; hence they will be beneficial irrespective of future climate change taking place. The United Kingdom Climate Impacts Programme (Willows and Connell 2003) has defined no-regret adaptation options (or measures) as: "options (or measures) that would be justified under all plausible future scenarios, including the absence of human-induced climate change". A no-regret option could be one that is worthwhile (in that it would yield economic and environmental benefits which exceed its cost), and will continue to be worthwhile, irrespective of any benefits of avoided climate damages. Options that score high on the criterion co-benefit are specifically designed to reduce climatechange related vulnerability while also producing corollary benefits that are not related to climate change (Abramovitz et al. 2002). Co-benefits thus concern external effects which have a positive impact on policy goals unrelated to climate change policy (Metroeconomica 2004).

Finally, the options are scored according to their effect on mitigation. Certain adaptation options will also induce a reduction of greenhouse gas emissions, and thus score very high on mitigation effect (i.e. are strengthening mitigation policies), while other adaptation options actually increase greenhouse gas emissions. Scores were attached for each of the options and for each of the criteria, ranging from 1-5, indicating very low priority (1) to very high priority (5).

In order to inform policymakers on the feasibility of the adaptation options, a separate sub-project focused on assessing their feasibility in the phase of implementation. The feasibility has been scored based on the technical, societal and institutional complexity that accompany the implementation of the proposed measures. Technical complexity refers to the technical difficulties and challenges which accompany the realization of the adaptation option, such as the technical facilities that have to be realized or mobilized; the technological uncertainties which 
accompany the implementation; the uniqueness of the operation and its risks. Social complexity involves the diversity of values which are at stake when the option will be implemented, the changes which are necessary in the perceptions of stakeholders, the necessity of their cooperation, etc. This complexity expresses itself in: the number of parties which have a stake at the option (or its effects); the diversity in normative views of the concerned parties; the degree to which the option is controversial and generates resistance; and the necessity to generate consensus and frame convergence. As the institutional complexity of implementing an adaptation grows, there are more adjustments of the official, bureaucratic organizations, existing procedures and arrangements necessary, more cooperation between institutional separated domains and thus resulting in a bigger tension with existing practices and structures. Elements of institutional complexity are: clashes between institutional rules (for example because different departments use different sets of rules or make different demands on procedures and process arrangements which can be used in implementation trajectories); the organizational consequences of the option; the cooperative relations or associations which are necessary for the implementation; and the degree of renewal of the option in relation to existing arrangements. Scores were attached from $1-5$, ranging from very low (1) to very high (5) complexities.

\subsection{Ranking adaptation options}

The ranking of the adaptation options is done using Multi-Criteria Analysis (MCA), a common tool in decision analysis when there are multiple objectives. MCA uses the judgements of decision makers or experts or stakeholders on the importance of the various criteria to make rankings of the options according to the weights attached to the various criteria. Our method is basically interactive: each individual, group of individuals or decision maker or group of decision makers (or experts) can express the relevant weights to be used and then the ranking will be updated.

In this paper we report on a ranking based on criteria weighting. The ranking is based on weighted summation of the scores on the different criteria (Greening and Bernow 2004; Dodgson et al. 2000; Munda et al. 1994), where for the results reported in this paper, the scores and the weights are based on expert judgment in order to be able to compare across various sectors in society. In criteria weighting, weights are given to each criterion that are supposed to reflect the preferences of the decision makers and the weighted sum of the different criteria is used to rank the options. The main problem is choosing the appropriate weights. A possible candidate is equal weights; this mirrors an unweighted summation of the scores. Another relevant weighting is to give higher weights to importance and urgency, thereby indicating that these are essential criteria. Our system allows for a wide variety of weights to be applied in an interactive manner in order to study the ranking under a wide variety of weights. By setting the weights of certain criteria to zero it is also possible to focus on a limited number of criteria.

Although we are convinced that the adopted ordering and weights in this paper bear empirical relevance, which was confirmed by an expert workshop of September 1st 2006 with key stakeholders and scientific experts, we do not claim that these are 'objective' or can be considered final, but rather they represent a suitable starting point for further discussions and analysis. These discussions are ongoing and will 
continue until the national strategy for climate adaptation in the Netherlands will be presented in 2009.

\subsection{Inventory of the incremental costs and benefits}

A preliminary inventory has been made of the incremental costs and benefits of adaptation options, in order to assess the order of magnitude of these in support of decision making on adaptation and to identify the knowledge gaps in this respect. For each option, the cost and benefit items are first described qualitatively and second for some options monetary estimate ranges are presented in quantitative terms (Euros). The costs and benefits of the adaptation options are computed in preparation for a Social Cost-Benefit Analysis (SCBA), an evaluation method based on welfare economics. ${ }^{4}$ The objective of a SCBA is to have insight in all costs and benefits for society as a whole, including external social and environmental costs and benefits. The Net Present Value of the costs of adaptation options has been calculated using a discount rate of $4 \%$, as suggested in the guidelines of the Dutch government for SCBA. ${ }^{5}$

\section{Results}

In the first step of our assessment (the literature survey and the stakeholder workshops) 96 adaptation options have been identified and described which reduce the vulnerability of the Netherlands to the effects of climate change. As the options have been taken from the literature or have been suggested by a wide range of stakeholders, they include a wide variety of policy measures, technological solutions and adjustments in behaviour (see Table 6 in "Appendix" for a complete overview of the identified options). We consider this an inevitable aspect of the stakeholder approach where many different perspectives are represented, and it seems to be inherent to the adaptation issue.

\subsection{Scoring and ranking of the adaptation options}

The identified adaptation options were scored on their different characteristics: importance, urgency, no-regret characteristics, co-benefits for other domains, and mitigation effect by experts directly involved in the identification of the options and through an expert workshop in which experts with broad experience on adaptation participated. The ranking of the options is made using criteria weighting. The ranking on feasibility (technical, societal and institutional complexity) was done in a separate

\footnotetext{
${ }^{4}$ A social cost-benefit analysis allows for the estimation of the net benefits of a project not only on the basis of the direct costs and benefits of such projects but also by considering the indirect or external effects in order to be able to assess the total welfare effects of public projects.

${ }^{5}$ Note that since the assessment of the options for this project, the official discount rate to be used in SCBA has been changed to $2.5 \%$. A lower discount rate would result in a higher discounted stream of future costs and benefits.
} 
sub-project by experts in public administration and policy planning, in order to provide additional information in this respect. ${ }^{6}$

\subsubsection{Ranking based on evaluation criteria}

The ranking is based on a weighted summation of the scores on the criteria (i) importance (weight $40 \%$ ), (ii) urgency (weight 20\%), (iii) no-regret characteristics (weight $15 \%$ ), (iv) co-benefits (weight $15 \%$ ) and (v) mitigation effect (weight $10 \%$ ). ${ }^{7}$

From the ranking, the following adaptation options have the highest priority (see Table 2):

- Integrated nature and water management (nr. 34);

- Integrated coastal zone management (nr. 35);

- More space for water: a. regional water system, b. improving river capacity (nr. 40);

- $\quad$ Risk based allocation policy (nr. 41);

- Risk management as basic strategy (nr. 65).

- New institutional alliances (nr. 68)

These options will emerge among the highest ranked almost regardless of the way the criteria are ordered, as their score is high on all criteria. Changing the order of the criteria will only affect options that score better on some criteria than on others. For instance, Water storage on farmland (nr. 07) scores very high on no-regret and high on urgency and co-benefits, but only medium on importance and mitigation effect. Therefore, when importance has a relatively high weight, this option has a relatively low ranking, whereas it ranks just below the top when no-regret characteristics are prioritised. It will always be below the top options mentioned above, however.

There are some options that score (very) low on all criteria and therefore rank very low (See Table 6 in "Appendix"). These options are:

- Subsoil drainage of peatlands (nr. 08);

- Reclamation of (part of) southern North Sea (nr. 52);

- Abandoning of the whole of low-lying Netherlands (nr. 53);

- Self sufficiency in production of roughage (nr. 06).

These options have very different characteristics but are either relatively far-fetched or unnecessary or very costly (for instance abandoning low-lying Netherlands!), or not directly related to adaptation to climate change.

\subsubsection{Ranking according to feasibility criteria}

For the ranking according to the feasibility of the adaptation options, the following criteria weighting is used for technical complexity (20\%), societal complexity $(40 \%)$

\footnotetext{
${ }^{6}$ In principle it is possible to include feasibility directly in the list of criteria, but we considered the feasibility issues as too distinct from the criteria on importance, urgency, no regret, co-benefits and mitigation effect, and we preferred a separate listing. The ranking system however allows full integration of the feasibility criteria in ranking by weighted summation for those that prefer an integrated MCA.

${ }^{7}$ This ordering is in line with the expert judgement as expressed in the expert workshop of September $1^{\text {st }} 2006$, although at an individual level some discrepancies exist.
} 


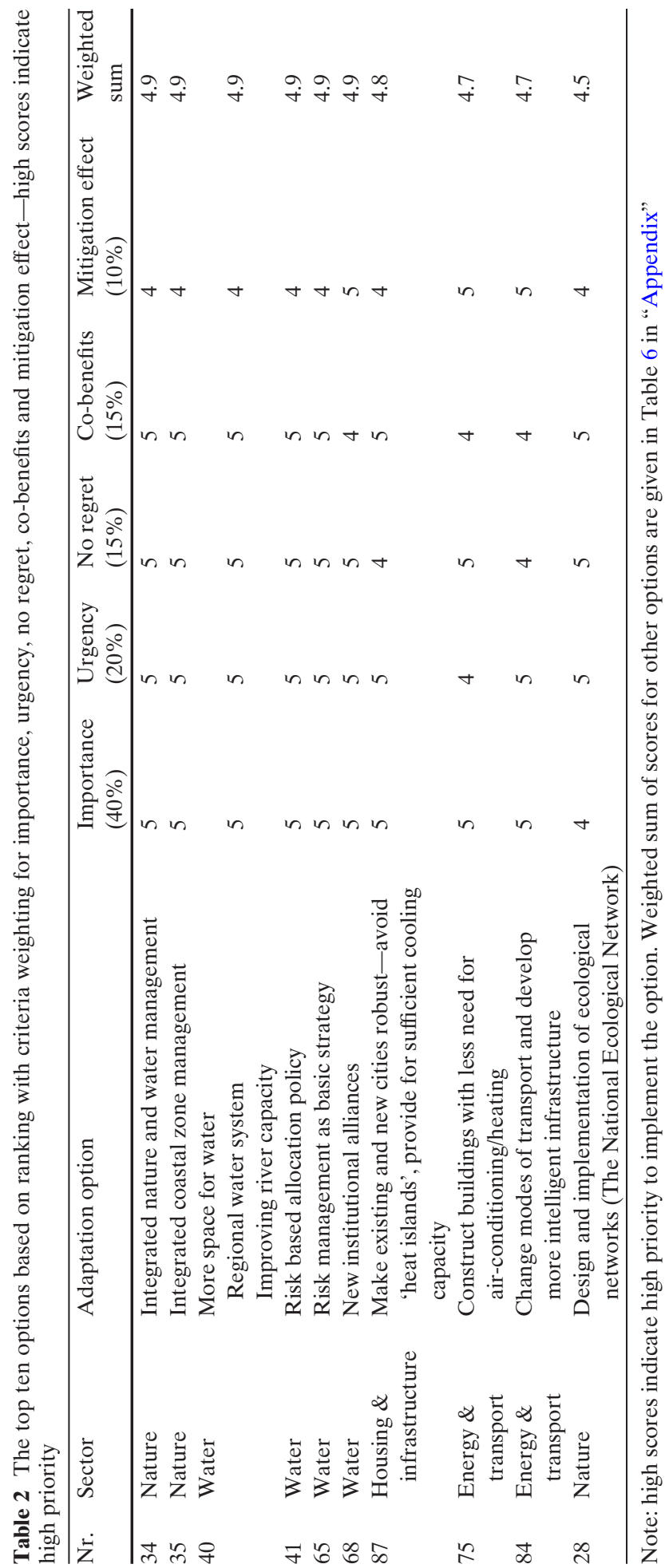


and institutional complexity (40\%). Table 3 presents the highest ranked adaptation options according to their feasibility; note that a high score reflects a high level of complexity, and hence a low level of feasibility.

Some adaptation options are technically relatively easy to implement. However, that does not say anything about the social and institutional complexity that their implementation brings about. These forms of complexity are much more difficult to handle. Implementing the adaptation options therefore requires a careful scan of the social and institutional environment in which they have to take place.

The feasibility analysis shows that many important and significant adaptation options encounter huge institutional complexities. This underlines that new, flexible and timely institutional arrangements are necessary to make an effective and smooth implementation of adaptation options possible.

There seems to be a weak relation between the feasibility of adaptation options and their ranking (in Section 3.1.1/Table 2). ${ }^{8}$ We see that the top 4 options on priority show feasibility scores between 4.2 and 4.4 indicating a relatively high level of complexity. The next options on the priority list show complexity in the range of 2.6-4.2, which indicates intermediate complexities. There are numerous counterexamples: some very important and urgent options (like educational programs (38) and some more technical options) are relatively well feasible and generate little social and institutional complexity compared to some less important and urgent options (abandoning of low-lying Netherlands (53), relocation of farms (13), reclamation of (part of) southern North Sea (52)) that are very complex to implement. So, in every case a specific analysis is necessary regarding the complexity conditions for implementation.

\subsection{Inventory of the incremental costs and benefits of adaptation options}

Ideally a Social Cost-Benefit Analysis (SCBA) should be performed for each of the options. It has, however, been difficult to acquire detailed information on the costs and benefits related to the identified adaptation options. Much of the information that is needed for a proper SCBA of the adaptation options is not yet available; information is especially missing on the indirect and external economic and environmental effects of the options. Therefore only preliminary and incomplete estimates are presented. Detailed additional research about the economic and environmental effects is needed in order to improve the rough estimates presented in this paper and to allow a proper quantitative assessment of adaptation priorities.

Table 4 presents an indication of the costs and benefits of adaptation options, as far as available. The overview shows that several prioritised adaptation policies will cost many billions of Euros in terms of net present value over the period from 2006 to 2050. Furthermore, within the field of spatial planning billions of Euros will have to be invested to reserve space, possibly to construct additional dikes in low lying parts of the country and make infrastructure climate proof. Additionally within the private sector, investments are important to prepare the Dutch economy for the envisaged climatic changes. These investments need to fit within the ongoing investment

${ }^{8}$ The priority ranking and the feasibility ranking is shown for all options in the last two columns in Table 6 in "Appendix". 


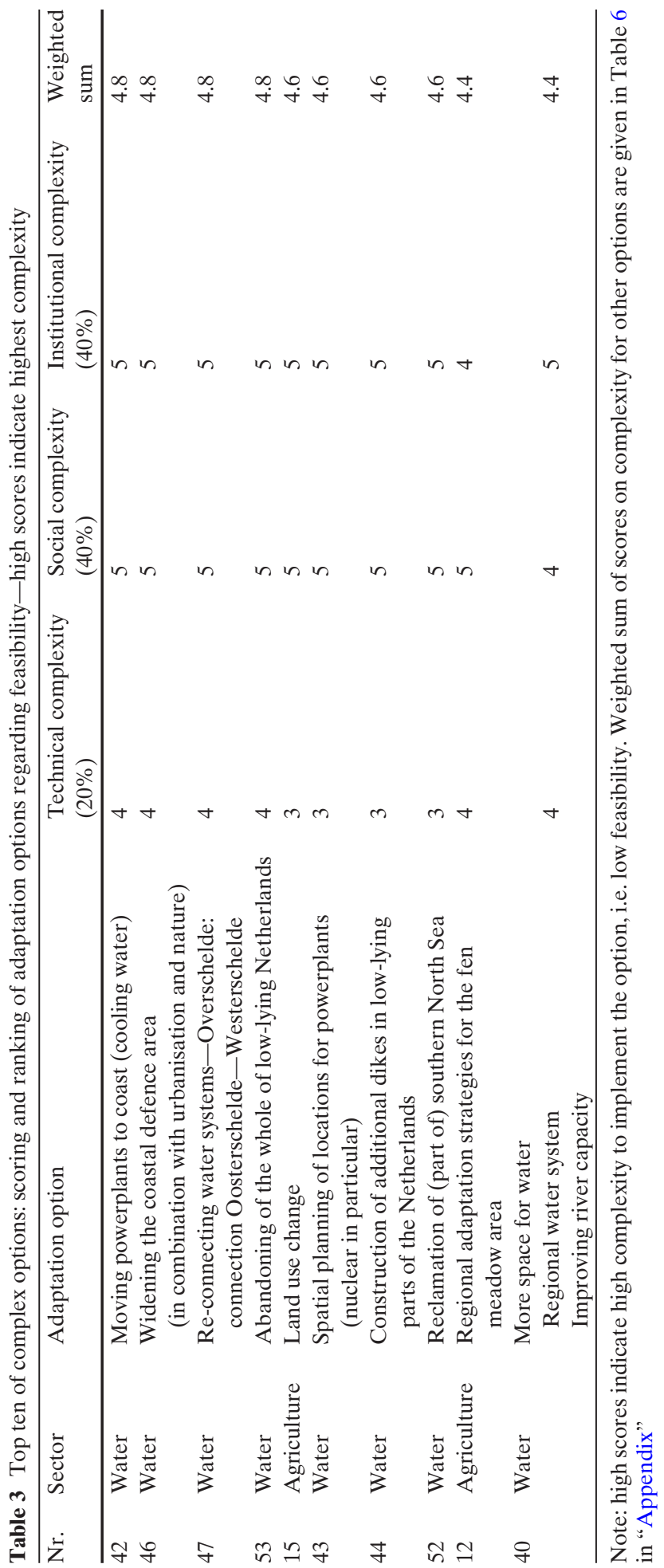


Table 4 Indication of the costs and benefits of adaptation options (as far as available)

\begin{tabular}{|c|c|c|c|c|}
\hline $\mathrm{Nr}$. & Sector & Adaptation option & $\begin{array}{l}\text { Costs } \\
(\text { million } €)^{\mathrm{a}}\end{array}$ & $\begin{array}{l}\text { Benefits } \\
(\text { million } €)^{b}\end{array}$ \\
\hline \multirow[t]{3}{*}{$\overline{40}$} & Water & More space for water & & \\
\hline & & Regional water system & 19,000 & $\mathrm{~N} / \mathrm{A}$ \\
\hline & & Improving river capacity & $>7,000$ & \\
\hline 41 & Water & Risk based allocation policy & $0-10$ & $\mathrm{~N} / \mathrm{A}$ \\
\hline 87 & $\begin{array}{l}\text { Housing \& } \\
\text { infrastructure }\end{array}$ & $\begin{array}{l}\text { Make existing and new cities robust_-avoid } \\
\text { 'heat islands', provide for sufficient cooling } \\
\text { capacity }\end{array}$ & $54-65 € / \mathrm{m}^{2}$ & $>225$ \\
\hline 75 & $\begin{array}{l}\text { Energy \& } \\
\text { transport }\end{array}$ & $\begin{array}{l}\text { Construct buildings with less need for } \\
\text { air-conditioning/heating }\end{array}$ & 23,000 & N/A \\
\hline 28 & Nature & $\begin{array}{l}\text { Design and implementation of ecological } \\
\text { networks (The National Ecological Network) }\end{array}$ & 7,000 & $>7,000$ \\
\hline 31 & Nature & Afforestation and mix of tree species & $0.43 /$ ha & $>0.43 /$ ha \\
\hline 46 & Water & $\begin{array}{l}\text { Widening the coastal defence area } \\
\text { (in combination with urbanisation and nature) }\end{array}$ & 1,000 & N/A \\
\hline 55 & Water & $\begin{array}{l}\text { Re-enforcement of dikes and dams, including } \\
\text { 'weak spots' }\end{array}$ & $>5,000$ & $\mathrm{~N} / \mathrm{A}$ \\
\hline 89 & $\begin{array}{l}\text { Housing \& } \\
\text { infrastructure }\end{array}$ & $\begin{array}{l}\text { Water management systems: revision of } \\
\text { sewer system }\end{array}$ & $3,000-5,000$ & N/A \\
\hline 37 & Nature & $\begin{array}{l}\text { Monitoring nature, interpreting changes } \\
\text { and informing }\end{array}$ & 340 & $>340$ \\
\hline 51 & Water & Relocation of fresh water intake points & $50-100$ & $\mathrm{~N} / \mathrm{A}$ \\
\hline 90 & $\begin{array}{l}\text { Housing \& } \\
\text { infrastructure }\end{array}$ & $\begin{array}{l}\text { Water management systems: options for water } \\
\text { storage and retention in or near city areas }\end{array}$ & 3,300 & N/A \\
\hline 73 & $\begin{array}{l}\text { Energy \& } \\
\text { transport }\end{array}$ & $\begin{array}{l}\text { Lowering the discount factor for project } \\
\text { appraisal }\end{array}$ & 0 & N/A \\
\hline 81 & $\begin{array}{l}\text { Energy \& } \\
\text { transport }\end{array}$ & Development of cooling towers & $275-550$ & $6.6-11$ \\
\hline 07 & Agriculture & Water storage on farmland & $15-50$ & N/A \\
\hline 49 & Water & Higher water level IJsselmeer & $>500$ & N/A \\
\hline 54 & Water & Increase sand suppletions along coast & $750-1,500$ & N/A \\
\hline
\end{tabular}

$N / A$ not available

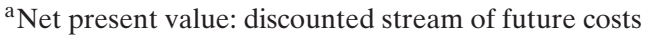

${ }^{b}$ Net present value: discounted stream of future benefits

trajectories of the different economic sectors and the costs will differ considerably between the different sectors. Also the costs and benefits depend on location, specific circumstances and the exact phasing of the measures, which require detailed SCBA in order to prioritise adaptation options for these locations. Unfortunately, several options that are prioritised in the qualitative assessment cannot yet be evaluated quantitatively, and hence these are missing from Table 4. This implies that Table 4 cannot be used as a priority list of adaptation options, nor can the costs be aggregated over the options to gain insight in the total costs of adaptation policy for the coming decades. For these analyses, more information is required.

Adaptation options involving relatively high costs are typically those for maintaining safety against flooding, but it is not easy to assess which part of the costs are required for maintenance of the existing safety standards and which part of the costs are explicitly related to changes induced by climate change. Many factors are 
interacting in determining sea level and river discharge and the exact role of climate change is difficult to determine, also because soil subsidence occurs in some parts of the Netherlands.

Another category involving high costs is the adaptation of housing and buildings in order to cope with higher temperatures. This will involve several tens of billions of Euros in net present value terms for the coming decades (until 2050). For the ecological network additional costs would be involved if an expansion of the network would be required to cope with the impacts of climate change.

\section{Discussion and conclusion}

In this study, an inventory was made of adaptation options for the Netherlands. The inventory was sector based, but the options can also be classified in several other ways. It turned out that the costs and benefits of the adaptation options can be estimated with reasonable accuracy for only a limited number of options. For the majority of the options knowledge gaps exist, data are missing or their reliability is insufficient. This means that based on our current knowledge it is impossible to evaluate the costs and benefits of the various policy alternatives and adaptation options that we presented. If we intend to use the database on adaptation options for selection of effectiveness and determination of costs, additional research is required to improve and expand the information that it contains so far. As the costs and benefits depend on location, specific circumstances and the exact phasing of the measures, detailed studies in so-called hotspot areas are indispensable. It also requires an analysis of the administrative and policy context at the level appropriate for specific adaptation options, on a local, regional, national and international level, and/ or at the level of the ecosystems under study.

The strength of the MCA approach is that it provides a ranking of options that can be used in further discussions and decisions on the adaptation strategy in the Netherlands. The method is useful in communication with the stakeholders and in raising awareness about the challenges of adaptation and the various options to do so. A set of top priority options could be identified based on expert judgement and at relatively low research costs. A weakness of the approach is that it does not yet provide a full social cost-benefit analysis of the options we have identified. We suggest to further develop the database on adaptation options and to continue with obtaining better data on costs of the options and where possible the monetary estimates of the benefits. This, however, cannot be done at a general level but would require specific studies at specific hotspots. These have now been defined and research in this direction is currently ongoing in the National Research Programme on Climate Change and Spatial Planning (Climate Change and Spatial Planning 2008).

From the analysis we observe the following. Several of these options relate to water management, especially for inland and coastal areas and the nature and agriculture sector. It is necessary to carefully check whether the current institutions (for instance the waterboards or the local authorities) can handle the challenges posed by climatic change and whether they are suited to implement the identified adaptation options. Improved coping capability of institutions can be achieved through the cooperation of institutions and stakeholders in new alliances (for instance through 
restructuring of the institutions responsible for protection against flooding) or through embedding adaptation policies systematically into existing institutions. Problems may, however, arise when the urgency of the local and regional institutions differ from the national level. It is thus important that the national institutions have a coordinating role in the area of spatial planning, and management of water and nature.

Adaptation options dealing with security (including water management) require much attention. It is necessary to improve evacuation plans and evacuation routes and also additional dikes can be constructed in vulnerable regions in order to reduce damages. Public utilities are important, because security risks occur if electricity generation will be hampered due to a possible shortage of cooling water in periods with high temperatures and low precipitation. Moreover it is important that overhead electricity transmission poles and high-tension cables are sufficiently strong and able to resist extreme weather events. Water management needs to be adapted in order to secure safe and sufficient drinking water. For public health, heat stress is an important risk. To reduce these risks, it is important to improve air conditioning in hospitals and nursing homes and to improve provision of good information. Attention should also be paid to preventing negative effects of toxic algae and an increase of disease (like Lyme disease).

Adaptation of traffic infrastructure is necessary to reduce the number of climate related disturbances. Possibilities are measures to reduce inundation of tunnels, facilities to deal with problems related to low river water levels, or measures to reduce disturbances of public transport due to extreme weather events. Also important are adaptations in the agricultural sector, forestry and fisheries. This concerns adaptation of production systems, changes in crop and variety choice, improvements in water management, (e.g. irrigation) and risk spreading for example, by developing new insurances and improving ecosystem management in the fisheries sector. The industry sector, especially the risk prone industries (e.g. refineries, petrochemical or chemical industry), should consider changes in temperature, precipitation and weather extremes in order to avoid calamities.

In the long run, the spatial planning of the Netherlands as well as plans to build in flood prone areas should be reconsidered. In new construction and city plans it is essential to use natural cooling, to prevent so-called 'heat islands' and to provide enough green areas so that cities remain pleasant, also when temperatures are high, without the need to use air conditioning. This requires a more climate oriented design of houses and offices.

For ecology, strengthening the National Ecological Network and integrated water management remain important.

Improved harmonization and coordination between different policy making and executing institutions is needed especially in areas where fine tuning between the central government, the provinces, and other stakeholders is a prerequisite for successful implementation, e.g. in the domain of water management. It is important to strengthen existing initiatives and develop new alliances, as well as making a clear division and coordination of the different tasks. Communication and consciousnessraising is important to prepare the Dutch society to climate change. Finally, it is 
very important to create transparency on the responsibilities and tasks of the various authorities and stakeholders, and to make clear what the role of the various authorities, producers, consumers and other stakeholders are in dealing with the impacts of climate change.

Acknowledgements We like to thank Ron Janssen (IVM-VU Amsterdam) and three anonymous reviewers for their useful comments. This paper reports on the Routeplanner study, which was commissioned by the national research programme on climate change and spatial planning in close cooperation with the Ministry of Housing, Spatial Planning and the Environment and aims to contribute to the preparation of the Dutch adaptation strategy to climate change. We thank Aalt Leusink and Ralph Lasage for their support within the Routeplanner project.

\section{Appendix}

Table 5 Organisations from which experts or stakeholders were represented

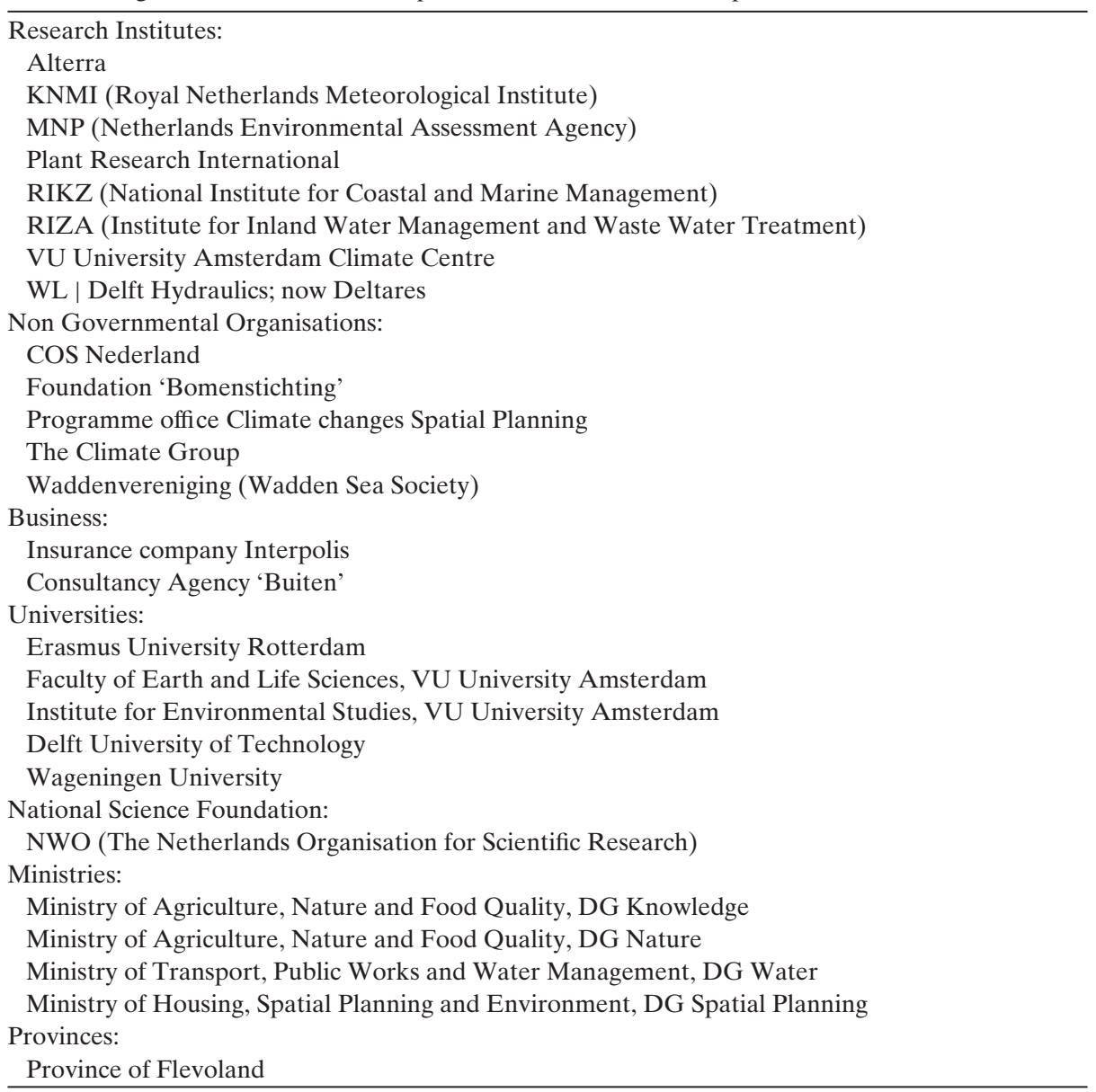


Table 6 List of adaptation options based on literature survey and stakeholder consultation, ordered by sector

\begin{tabular}{|c|c|c|c|c|}
\hline Nr. & Sector & Adaptation option & $\begin{array}{l}\text { Weighted } \\
\text { sum-ranking } \\
\text { importance, } \\
\text { urgency, } \\
\text { no regret, } \\
\text { co-benefits and } \\
\text { mitigation effect }\end{array}$ & $\begin{array}{l}\text { Weighted } \\
\text { sum-ranking } \\
\text { complexity }\end{array}$ \\
\hline 1 & Agriculture & $\begin{array}{l}\text { Adjusting crop rotation schemes } \\
\text { and planting and harvesting dates }\end{array}$ & 3.1 & 3.4 \\
\hline 2 & Agriculture & Choice of crop variety and genotype & 3.5 & 3.4 \\
\hline 3 & Agriculture & $\begin{array}{l}\text { Development and growing of crops } \\
\text { for biomass production }\end{array}$ & 2.8 & 3.2 \\
\hline 4 & Agriculture & Soil moisture conservation practices & 3.6 & 2.4 \\
\hline 5 & Agriculture & Irrigation & 2.9 & 3.2 \\
\hline 6 & Agriculture & $\begin{array}{l}\text { Self sufficiency in production } \\
\text { of roughage }\end{array}$ & 1.6 & 2.6 \\
\hline 7 & Agriculture & Water storage on farmland & 3.7 & 3.4 \\
\hline 8 & Agriculture & Subsoil drainage of peatlands & 1.2 & 3.6 \\
\hline 9 & Agriculture & Insurance & 3.1 & 3.2 \\
\hline 10 & Agriculture & Changes in farming systems & 3.8 & 3.4 \\
\hline 11 & Agriculture & Water management and agriculture & 3.4 & 4 \\
\hline 12 & Agriculture & $\begin{array}{l}\text { Regional adaptation strategies for the } \\
\text { fen meadow area }\end{array}$ & 3 & 4.4 \\
\hline 13 & Agriculture & Relocation or mobilization of farms & 1.6 & 4.2 \\
\hline 14 & Agriculture & Floating greenhouses & 1.9 & 2.8 \\
\hline 15 & Agriculture & Land use change & 3.3 & 4.6 \\
\hline 16 & Agriculture & $\begin{array}{l}\text { Adaptation strategies to salinization } \\
\text { of agricultural land }\end{array}$ & 2.6 & 4 \\
\hline 17 & Agriculture & $\begin{array}{l}\text { Increasing genetic and species } \\
\text { diversity in forests }\end{array}$ & 4.4 & 2.8 \\
\hline 18 & Agriculture & $\begin{array}{l}\text { Introduction of southern provenances } \\
\text { of tree species and drought resistant } \\
\text { species }\end{array}$ & 3.9 & 2.2 \\
\hline 19 & Agriculture & Limiting the import of timber & 1.6 & 3.2 \\
\hline 20 & Agriculture & $\begin{array}{l}\text { Retention of winter precipitation } \\
\text { in forests }\end{array}$ & 2.6 & 2.2 \\
\hline 21 & Agriculture & $\begin{array}{l}\text { Acceptation of changes in species } \\
\text { composition in forests }\end{array}$ & 3.9 & 2.4 \\
\hline 22 & Agriculture & Adjusting fishing quota & 2.6 & 3 \\
\hline 23 & Agriculture & $\begin{array}{l}\text { Adaptation of target species and } \\
\text { fishing techniques }\end{array}$ & 2.2 & 2.8 \\
\hline 24 & Agriculture & $\begin{array}{l}\text { Introduction of ecosystem management } \\
\text { in fishery }\end{array}$ & 4.2 & 3.8 \\
\hline 25 & Agriculture & Eco-labelling and certification of fish & 1.5 & 3 \\
\hline 26 & Agriculture & Reallocation of mussel nursery plots & 2.3 & 3.2 \\
\hline 27 & Agriculture & Aquaculture on former grassland & 1.8 & 3.4 \\
\hline 28 & Nature & $\begin{array}{l}\text { Design and implementation of } \\
\text { ecological networks (The National } \\
\text { Ecological Network) }\end{array}$ & 4.5 & 3.6 \\
\hline 29 & Nature & $\begin{array}{l}\text { Establishment and management } \\
\text { of protected areas }\end{array}$ & 3.4 & 3.4 \\
\hline
\end{tabular}


Table 6 (continued)

\begin{tabular}{|c|c|c|c|c|}
\hline Nr. & Sector & Adaptation option & $\begin{array}{l}\text { Weighted } \\
\text { sum-ranking } \\
\text { importance, } \\
\text { urgency, } \\
\text { no regret, } \\
\text { co-benefits and } \\
\text { mitigation effect }\end{array}$ & $\begin{array}{l}\text { Weighted } \\
\text { sum-ranking } \\
\text { complexity }\end{array}$ \\
\hline 30 & Nature & Artificial translocation of plant and animal & 1.6 & 3.6 \\
\hline 31 & Nature & Afforestation and mix of tree species & 4.3 & 2.8 \\
\hline 32 & Nature & Adjustment of forest management & 3.7 & 2.6 \\
\hline 33 & Nature & $\begin{array}{l}\text { Implementation of effective agri- } \\
\text { environmental schemes }\end{array}$ & 3.6 & 4 \\
\hline 34 & Nature & Integrated nature and water management & 4.9 & 4.2 \\
\hline 35 & Nature & Integrated coastal zone management & 4.9 & 4.2 \\
\hline 36 & Nature & $\begin{array}{l}\text { Restoration of ecosystems directly depending } \\
\text { on water quantity and quality }\end{array}$ & 3.3 & 3.8 \\
\hline 37 & Nature & $\begin{array}{l}\text { Monitoring nature, interpreting changes } \\
\text { and informing }\end{array}$ & 4.1 & 2.6 \\
\hline 38 & Nature & Educational programs & 4.3 & 2 \\
\hline 39 & Nature & Development of financing mechanisms & 2.6 & 4 \\
\hline 40 & Water & $\begin{array}{l}\text { More space for water: } \\
\text { Regional water system } \\
\text { Improving river capacity }\end{array}$ & 4.9 & 4.4 \\
\hline 41 & Water & Risk based allocation policy & 4.9 & 4.4 \\
\hline 42 & Water & Moving powerplants to coast (cooling water) & 3.2 & 4.8 \\
\hline 43 & Water & $\begin{array}{l}\text { Spatial planning of locations for powerplants } \\
\text { (nuclear in particular) }\end{array}$ & 4 & 4.6 \\
\hline 44 & Water & $\begin{array}{l}\text { Construction of additional dikes in low-lying } \\
\text { parts of the Netherlands }\end{array}$ & 3.5 & 4.6 \\
\hline 45 & Water & $\begin{array}{l}\text { Allow transgression of sea in wide dune areas, } \\
\text { allow wash over of dikes }\end{array}$ & 3.4 & 3.8 \\
\hline 46 & Water & $\begin{array}{l}\text { Widening the coastal defence area } \\
\text { (in combination with urbanisation and nature) }\end{array}$ & 4.2 & 4.8 \\
\hline 47 & Water & $\begin{array}{l}\text { Reconnecting water systems in Delta area } \\
\text { (e.g. Volkerak Zoommeer and Oosterschelde) }\end{array}$ & 3.3 & 4.8 \\
\hline 48 & Water & $\begin{array}{l}\text { Fresh water storage to flush brackish water } \\
\text { out during dry periods }\end{array}$ & 4.3 & 4 \\
\hline 49 & Water & Higher water level IJsselmeer & 3.6 & 3.4 \\
\hline 50 & Water & $\begin{array}{l}\text { Maintain higher water table to prevent salt } \\
\text { water intrusion }\end{array}$ & 4.3 & 3.8 \\
\hline 51 & Water & Relocation of fresh water intake points & 4 & 2.4 \\
\hline 52 & Water & Reclamation of (part of) southern North Sea & 1.4 & 4.6 \\
\hline 53 & Water & $\begin{array}{l}\text { Abandoning of the whole of low-lying } \\
\text { Netherlands }\end{array}$ & 1.3 & 4.8 \\
\hline 54 & Water & Increase sand suppletions along coast & 3.5 & 2.8 \\
\hline 55 & Water & $\begin{array}{l}\text { Re-enforcement of dikes and dams, } \\
\text { including 'weak spots' }\end{array}$ & 4.2 & 2.2 \\
\hline 56 & Water & Adapted forms of building and construction & 4 & 3.6 \\
\hline 57 & Water & $\begin{array}{l}\text { Adaptation of highways, secondary dikes } \\
\text { to create compartments }\end{array}$ & 4 & 4 \\
\hline 58 & Water & Protection of vital objects & 3.1 & 2.6 \\
\hline$\underline{59}$ & Water & Protection of vital infrastructure & 3.1 & 3.4 \\
\hline
\end{tabular}


Table 6 (continued)

\begin{tabular}{|c|c|c|c|c|}
\hline $\mathrm{Nr}$ & Sector & Adaptation option & $\begin{array}{l}\text { Weighted } \\
\text { sum-ranking } \\
\text { importance, } \\
\text { urgency, } \\
\text { no regret, } \\
\text { co-benefits and } \\
\text { mitigation effect }\end{array}$ & $\begin{array}{l}\text { Weighted } \\
\text { sum-ranking } \\
\text { complexity }\end{array}$ \\
\hline 60 & Water & Enhancing capacity of sluices and weirs & 3.6 & 2 \\
\hline 61 & Water & $\begin{array}{l}\text { Artificial reefs along the coastline \& } \\
\text { development nature conservation } \\
\text { values }\end{array}$ & 1.8 & 2.8 \\
\hline 62 & Water & De-salinization & 1.5 & 2 \\
\hline 63 & Water & Reduction salt water tongue & 2.8 & 2.8 \\
\hline 64 & Water & $\begin{array}{l}\text { Stimulate economic activity in other parts } \\
\text { (eastern and northern) of the Netherlands }\end{array}$ & 4 & 3.2 \\
\hline 65 & Water & Risk management as basic strategy & 4.9 & 3.2 \\
\hline 66 & Water & Evacuation plans & 4.5 & 4 \\
\hline 67 & Water & Creating public awareness & 4.2 & 3.2 \\
\hline 68 & Water & New institutional alliances & 4.9 & 4 \\
\hline 69 & Water & $\begin{array}{l}\text { Private insurances against inundations } \\
\text { and/or drought related damages }\end{array}$ & 3 & 3.6 \\
\hline 70 & Water & $\begin{array}{l}\text { Reduce wastewater discharge during } \\
\text { drought periods }\end{array}$ & 3.6 & 3.8 \\
\hline 71 & $\begin{array}{l}\text { Energy \& } \\
\text { transport }\end{array}$ & $\begin{array}{l}\text { Adapt regulations such that a higher } \\
\text { discharge temperature is allowed }\end{array}$ & 2.3 & 2.8 \\
\hline 72 & $\begin{array}{l}\text { Energy \& } \\
\text { transport }\end{array}$ & Sluices & 2.8 & 2.2 \\
\hline 73 & $\begin{array}{l}\text { Energy \& } \\
\text { transport }\end{array}$ & $\begin{array}{l}\text { Lowering the discount factor for } \\
\text { project appraisal }\end{array}$ & 4 & 3 \\
\hline 74 & $\begin{array}{l}\text { Energy \& } \\
\text { transport }\end{array}$ & Building stronger wind turbines & 2.4 & 2.6 \\
\hline 75 & $\begin{array}{l}\text { Energy \& } \\
\text { transport }\end{array}$ & $\begin{array}{l}\text { Construct buildings less need for } \\
\text { air-conditioning/heating }\end{array}$ & 4.7 & 2.6 \\
\hline 76 & $\begin{array}{l}\text { Energy \& } \\
\text { transport }\end{array}$ & $\begin{array}{l}\text { Constructing more stable overhead } \\
\text { electricity transmission poles }\end{array}$ & 3.7 & 2.2 \\
\hline 77 & $\begin{array}{l}\text { Energy \& } \\
\text { transport }\end{array}$ & Adapt to mitigation strategies & 3.4 & 2.4 \\
\hline 78 & $\begin{array}{l}\text { Energy \& } \\
\text { transport }\end{array}$ & $\begin{array}{l}\text { Use improved opportunities for } \\
\text { generating wind energy }\end{array}$ & 2.2 & 2.6 \\
\hline 79 & $\begin{array}{l}\text { Energy \& } \\
\text { transport }\end{array}$ & $\begin{array}{l}\text { Use improved opportunities for } \\
\text { generating solar energy }\end{array}$ & 2.2 & 2 \\
\hline 80 & $\begin{array}{l}\text { Energy \& } \\
\text { transport }\end{array}$ & Planting of biomass crops & 2.4 & 2.8 \\
\hline 81 & $\begin{array}{l}\text { Energy \& } \\
\text { transport }\end{array}$ & Development of cooling towers & 4 & 2.6 \\
\hline 82 & $\begin{array}{l}\text { Energy \& } \\
\text { transport }\end{array}$ & $\begin{array}{l}\text { Development of more 'intelligent' } \\
\text { infrastructure that can serve } \\
\text { as early warning indicator }\end{array}$ & 4.5 & 2.6 \\
\hline 83 & $\begin{array}{l}\text { Energy \& } \\
\text { transport }\end{array}$ & Improvement of vessels & 3.7 & 1.6 \\
\hline 84 & $\begin{array}{l}\text { Energy \& } \\
\text { transport }\end{array}$ & $\begin{array}{l}\text { Change modes of transport and develop } \\
\text { more intelligent infrastructure }\end{array}$ & 4.7 & 4 \\
\hline
\end{tabular}


Table 6 (continued)

\begin{tabular}{|c|c|c|c|c|}
\hline$\overline{\mathrm{Nr}}$ & Sector & Adaptation option & $\begin{array}{l}\text { Weighted } \\
\text { sum-ranking } \\
\text { importance, } \\
\text { urgency, } \\
\text { no regret, } \\
\text { co-benefits and } \\
\text { mitigation effect }\end{array}$ & $\begin{array}{l}\text { Weighted } \\
\text { sum-ranking } \\
\text { complexity }\end{array}$ \\
\hline 85 & $\begin{array}{l}\text { Energy \& } \\
\text { transport }\end{array}$ & $\begin{array}{l}\text { Increase standards for buildings as to } \\
\text { make them more robust to increased } \\
\text { wind speeds }\end{array}$ & 3.9 & 1.8 \\
\hline 86 & $\begin{array}{l}\text { Housing \& } \\
\text { infrastructure }\end{array}$ & $\begin{array}{l}\text { Design spatial planning-construct } \\
\text { new housing and infrastructure }\end{array}$ & 4.5 & 4 \\
\hline 87 & $\begin{array}{l}\text { Housing \& } \\
\text { infrastructure }\end{array}$ & $\begin{array}{l}\text { Make existing and new cities robust- } \\
\text { avoid 'heat islands', provide for } \\
\text { sufficient cooling capacity }\end{array}$ & 4.8 & 3 \\
\hline 88 & $\begin{array}{l}\text { Housing \& } \\
\text { infrastructure }\end{array}$ & $\begin{array}{l}\text { Design houses with good climate } \\
\text { conditions (control)_'low energy' }\end{array}$ & 4.5 & 2.4 \\
\hline 89 & $\begin{array}{l}\text { Housing \& } \\
\text { infrastructure }\end{array}$ & $\begin{array}{l}\text { Water management systems: revision } \\
\text { of sewer system }\end{array}$ & 4.2 & 2.4 \\
\hline 90 & $\begin{array}{l}\text { Housing \& } \\
\text { infrastructure }\end{array}$ & $\begin{array}{l}\text { Water management systems: options } \\
\text { for water storage and retention in } \\
\text { or near city areas }\end{array}$ & 4 & 3.8 \\
\hline 91 & $\begin{array}{l}\text { Housing \& } \\
\text { infrastructure }\end{array}$ & $\begin{array}{l}\text { Water management systems: emergency } \\
\text { systems revision for tunnels and } \\
\text { subways }\end{array}$ & 3.7 & 2.2 \\
\hline 92 & $\begin{array}{l}\text { Housing \& } \\
\text { infrastructure }\end{array}$ & New design of large infrastructure & 4.2 & 3.6 \\
\hline 93 & Health & $\begin{array}{l}\text { Improved air conditioning in nursery } \\
\text { homes or hospitals }\end{array}$ & 3.4 & 1 \\
\hline 94 & Health & $\begin{array}{l}\text { Measures for preventing climate related } \\
\text { diseases }\end{array}$ & 3.1 & 2.4 \\
\hline 95 & Health & $\begin{array}{l}\text { Improvement of health care for climate } \\
\text { related diseases }\end{array}$ & 3.3 & 2.2 \\
\hline 96 & $\begin{array}{l}\text { Recreation \& } \\
\text { tourism }\end{array}$ & $\begin{array}{l}\text { Design infrastructure for recreation and } \\
\text { tourism-coastal areas }\end{array}$ & 3.3 & 3.6 \\
\hline
\end{tabular}

Open Access This article is distributed under the terms of the Creative Commons Attribution Noncommercial License which permits any noncommercial use, distribution, and reproduction in any medium, provided the original author(s) and source are credited.

\section{References}

Abramovitz J, Banuri T, Girot PO, Orlando B, Schneider N, Spanger-Siegfried E, Switzer J, Hammill A (2002) Adapting to climate change: natural resource management and vulnerability reduction. Background paper to the task force on climate change, adaptation and vulnerable communities. International Institute for Sustainable Development, Manitoba

Bell ML, Hobbs BF, Elliott EM, Ellis H, Robinson Z (2001) An evaluation of multi-criteria methods in integrated assessment of climate policy. J Multi-Criteria Decis Anal 10:229-256

Belton V, Stewart TJ (2002) Multiple criteria decision analysis: an integrated approach. Kluwer Academic, Boston 
Brouwer R, van Ek R (2004) Integrated ecological, economic and social impact assessment of alternative flood control policies in the Netherlands. Ecol Econ 50:1-21

Burton I, Huq S, Lim B, Pilifosova O, Schipper EL (2002) From impact assessment to adaptation priorities: the shaping of adaptation policy. Clim Policy 2(2-3):145-149

Climate Change and Spatial Planning (2008) National research programme on climate change and spatial planning. www.klimaatvoorruimte.nl

DEFRA (2006) The UK's fourth national communication under the united nations framework convention on climate change. United Kingdom Department for Environment, Food and Rural Affairs, London, p 135

Dodgson J, Spackman M, Pearman A, Phillips L (2000) Multi-criteria analysis manual. Department of Transport, Local Government and the Regions, London. http://www.communities.gov.uk/ archived/publications/corporate/multicriteriaanalysismanual

Ebi KL, Burton I (2008) Identifying practical adaptation options: an approach to address climate change-related health risks. Environ Sci Policy 11:359-369

Fankhauser S, Smith JB, Tol RSJ (1999) Weathering climate change: some simple rules to guide adaptation decisions. Ecol Econ 30:67-78

Füssel H-M (2007) Adaptation planning for climate change: concepts, assessment approaches, and key lessons. Sustain Sci 2:265-275

Füssel H-M, Klein RJT (2006) Climate change vulnerability assessments: an evolution of conceptual thinking. Clim Change 75(3):301-329

Gough C, Shackley S (2006) Towards a multi-criteria methodology for assessment of geological carbon storage options. Clim Change 74:141-174

Greening LA, Bernow S (2004) Design of coordinated energy and environmental policies: use of multi-criteria decision-making. Energy Policy 32:721-735

IPCC (2007) Climate change 2007: impacts, adaptation and vulnerability. Summary for policymakers, working group II contribution to the intergovernmental panel on climate change, fourth assessment report.

Janssen R, van Herwijnen M (2006) A toolbox for multicriteria decision-making. Int J Environ Technol Manag 6:20-39

Keeney RL, Raiffa H (1976) Decisions with multiple objectives: preferences and value tradeoffs. Wiley, New York

KNMI (2003) De toestand van het klimaat in Nederland. KNMI, Bilthoven

KNMI (2006) Climate in the 21st century, four scenarios for the Netherlands. Royal Netherlands Meteorological Institute, Bilthoven

Lemmen DS, Warren FJ, Lacroix J, Bush E (eds) (2008) From impacts to adaptation: Canada in a changing climate 2007. Government of Canada, Ottawa, ON, p 448

McCarthy JJ, Canziani OF, Leary NA, Dokken DJ, White KS (eds) (2001) Climate change 2001: impacts, adaptation, vulnerability. Cambridge University Press, Cambridge

Metroeconomica (2004) Costing the impacts of climate change in the UK: overview of guidelines. UKCIP technical report. UKCIP, Oxford

MMM (2005) Finland's national strategy for adaptation to climate change. Ministry of Agriculture and Forestry of Finland, Helsinki, pp 281. http:/www.mmm.fi/fi/index/etusivu/ymparisto/ ilmastopolitiikka/ilmastomuutos.html

Munda G, Nijkamp P, Rietveld P (1994) Qualitative multicriteria evaluation for environmental management. Ecol Econ 10:97-112

RIVM (2004) Milieubalans 2004. Het Nederlandse milieu verklaard. RIVM rapport 251701057. Bilthoven, the Netherlands, p 200

Rooijers F, de Keizer I, Slingerland S, Faber J, Wit RCN, Verbeek J, van Dorland R, van Ulden AP, Hutjes R, Kabat P, van Ierland EC (2004) Klimaatverandering klimaatbeleid. Inzicht in keuzes voor de Tweede Kamer. Hoofdrapport September 2004. Rapport 3748

Rosenzweig C, Major DC, Demong K, Stanton C, Horton R, Stults M (2007) Managing climate change risks in New York city's water system: assessment and adaptation planning. Mitig Adapt Strategies Glob Chang 12:1391-1409

Smit B, Pilifosova O (2003) From adaptation to adaptive capacity and vulnerability reduction. In: Smith JB, Klein RJT, Huq S (eds) Climate change, adaptive capacity and development. Imperial College, London

Smit B, Burton I, Klein RJT, Street R (1999) The science of adaptation: a framework for assessment. Mitig Adapt Strategies Glob Chang 4:199-213

Smit B, Pilifosova O, Burton I, Challenger B, Huq S, Klein R, Yohe G (2001) Adaptation to climate change in the context of sustainable development and equity. In: McCarthy JJ, Canziani OF, 
Leary NA, Dokken DJ, White KS (eds) Climate change 2001: impacts, adaptation, vulnerability. Contribution of working group II to the third assessment report of the intergovernmental panel on climate change. Cambridge University Press, Cambridge

Stern N (2006) The economics of climate change. The Stern review. www.sternreview.org.uk

Tol RSJ, Klein RJT, Nicholls RJ (2008) Towards successful adaptation to sea-level rise along Europe's coasts. J Coast Res 24(2):432-442

UNDP (2005) Adaptation policy frameworks for climate change. Developing strategies, policies and measures. Cambridge University Press, Cambridge UK

UNFCCC (1997) Kyoto protocol to the united nations framework convention on climate change

UNFCCC (2007) National Adaptation Programmes of Action (NAPAs). http://unfccc.int/national_ reports/napa/items/2719.php

Van Ierland EC, de Bruin K, Dellink RB, Ruijs A (eds) (2007) A qualitative assessment of climate adaptation options and some estimates of adaptation costs. Reports on the Routeplanner projects 3, 4 and 5 (Routeplanner deelprojecten 3, 4 en 5), Wageningen UR. Available at www.enr.wur.nl/UK/Routeplanner+Report

Willows RI, Connell RK (eds) (2003) Climate adaptation: risk, uncertainty and decision making. UKCIP Technical Report. UKCIP, Oxford 